Ethiopian Journal of Environmental Studies \& Management 9(4): 481 - 492, 2016.

ISSN:1998-0507

doi: http://dx.doi.org/10.4314/ejesm.v9i4.8

Submitted: April 04, 2016

Accepted: July 22, 2016

\title{
COMPARATIVE STUDY OF BIOAVAILABILITY AND TRANSFER OF HEAVY METALS FROM IRRIGATION WATER AND SOIL TO Amaranthus spp. VEGETABLES
}

\author{
*ADEBAYO, G.B., ${ }^{1}$ ADEKOLA, O.F., ${ }^{2}$ AHMED, T.Y. ${ }^{1}$ AND ADEKOLA, F.A. ${ }^{1}$ \\ ${ }^{1}$ Department of Industrial Chemistry, University of Ilorin, Ilorin, Nigeria \\ ${ }^{2}$ Department of Agronomy, University of Ilorin, Ilorin, Nigeria
}

\begin{abstract}
The present investigation was on the assessment of concentrations of different heavy metals in irrigation water, agricultural soil and vegetables (Amaranthus spp.) grown on the University of Ilorin Teaching and Research Farm. The possible health hazard to humans through food chain transfer was discussed. Irrigation water, soil and Amaranthus spp. were analyzed for $\mathrm{Cr}, \mathrm{Co}, \mathrm{Ni}, \mathrm{Cu}, \mathrm{Pb}, \mathrm{Cd}, \mathrm{Mn}$, Fe and $\mathrm{Zn}$ concentrations. Transfer factors (TF), daily intake rate (DIR) and target hazard quotient (THQ) for daily consumption of $0.345 \mathrm{~kg}$ of the plant were evaluated using the data obtained from the analysis. The concentration of these metals in the soil were as follows; $\mathrm{Mn}(76.5-225.5$ $\mathrm{mg} / \mathrm{kg}), \mathrm{Fe}(2063.5-8697.0 \mathrm{mg} / \mathrm{kg}), \mathrm{Zn}(9.0-25.5 \mathrm{mg} / \mathrm{kg}), \mathrm{Cu}(2.0-8.0 \mathrm{mg} / \mathrm{kg}), \mathrm{Cr}(<0.1$ $-8.5 \mathrm{mg} / \mathrm{kg}), P b(<0.1-33.0 \mathrm{mg} / \mathrm{kg})$, while $\mathrm{Ni}$, Co and $\mathrm{Cd}$ were not detected $(<0.1 \mathrm{mg} / \mathrm{kg})$. Only $\mathrm{Mn}, \mathrm{Fe}, \mathrm{Cu}$ and $\mathrm{Zn}$ were detected in the irrigation water and in the plant were $\mathrm{Mn}$ $(0.41 \mathrm{mg} / \mathrm{L}), \mathrm{Fe}(0.30 \mathrm{mg} / \mathrm{L}), \mathrm{Cu}(0.02 \mathrm{mg} / \mathrm{L}), \mathrm{Zn}(0.02 \mathrm{mg} / \mathrm{L})$ and $\mathrm{Mn}(390-940 \mathrm{mg} / \mathrm{kg})$, Fe $(405-662.5 \mathrm{mg} / \mathrm{kg}), \mathrm{Cu}(0.00-10.0 \mathrm{mg} / \mathrm{kg}), \mathrm{Zn}(50.0-110.0 \mathrm{mg} / \mathrm{kg})$ respectively. The TF was in the order $\mathrm{Zn}>\mathrm{Mn}>\mathrm{Cu}>\mathrm{Fe}$, while the DIR were below the tolerable limits and the THQ were in the ranges $\mathrm{Zn}\left(1.05 \times 10^{-3}-2.31 \times 10^{-3}\right), \mathrm{Mn}\left(1.72 \times 10^{-2}-4.14 \times 10^{-2}\right)$, Fe $\left(3.56 \times 10^{-3}-5.83 \times 10^{-3}\right)$ and $\mathrm{Cu}\left(1.13 \times 10^{-3}-1.50 \times 10^{-3}\right)$. The results also showed that the levels of $\mathrm{Zn}, \mathrm{Fe}$ and $\mathrm{Mn}$ in the vegetables were higher than the international standards and the calculated THQs implied that these concentrations would have no adverse effect on the consumers over the period of time. However, the concentrations of the heavy metals need regular monitoring to prevent excessive build-up over time in the vegetable.
\end{abstract}

Key Words: Heavy metals, irrigation water, Bioavalaibilty, Amaranthus spp, health hazard.

\section{Introduction}

Heavy metals are significant environmental pollutants and their toxicity is a problem of increasing significance for ecological, evolutionary, nutritional and environmental reasons
(Nagajyot et al., 2010). During the period of low rainfall especially in the dry season, most farmers usually depend on the use of river or stream water for irrigation of vegetable beds (Dosumu et al., 2003) and these water bodies may

*Corresponding Author: Adebayo, G.B. 
have been polluted over time, acting as a source of heavy metals to soil. Soil to plant transfer of heavy metals is the major path way of human exposure to metal contamination (Jolly et al., 2013). If plants decay, these toxic metals are redistributed and as a consequence their enrichment in the agricultural soil occurs. The toxic heavy metals entering the ecosystem may lead to geoaccumulation, bioaccumulation and biomagnifications (Naser et al., 2012). Vegetable's uptake of metals from soil is one of the major pathways that metals enter into food chain as they contain essential nutrients and trace elements (Rasheed and Awadallah, 1998; Nwajei et al., 2012). It has been observed that among food system, vegetables are the most exposed food to environmental pollution due to aerial burden (Jolly et al., 2013).

Metals such as chromium, cobalt, copper, iron, manganese and zinc as micronutrients are essential with known biochemical functions while lead is nonessential with toxic effects (Audu and Lawal, 2006). It is only when metals are present in bioavailable forms and at excessive levels that they have the potential to become toxic to plants (Nagajyot et al., 2010). Some of these heavy metals are also called trace elements due to their presence in trace $\left(10 \mathrm{mg} \mathrm{kg}^{-1}\right)$ or in ultra-trace $\left(1 \mathrm{~g} \mathrm{~kg}^{-1}\right)$ quantities in the environmental matrices. The essential heavy metals have biochemical and physiological functions in plants and animals through Participation in redox reaction, and being an integral part of several enzymes. Heavy metals are significant environmental pollutants, and their toxicity is a problem of increasing significance for ecological, evolutionary, nutritional and environmental reasons (Nagajyoti, 2010).

Heavy metals can be found generally at trace levels in soil and vegetation. However, these have a toxic effect on organisms at high levels of concentration. Heavy metals toxicity has an inhibitory effect on plant growth, enzymatic activity, stoma function, photosynthesis activity and accumulation of other nutrient elements, and also damages the root system (Noorikh et al., 2013). Furthermore, consumption of heavy metals-contaminated food can seriously deplete some essential nutrients in the body causing a decrease in immunological defenses, intrauterine growth retardation, impaired psychosocial behavior, disabilities associated with malnutrition and a high prevalence of upper gastrointestinal cancer (Ramesh and Yogananda, 2012). Prolonged consumption of contaminated foodstuff may lead to the unceasing accumulation of toxic metals in the liver and kidney of humans resulting in the disturbance of biochemical processes, such as, liver, kidney, cardiovascular, nervous and bone disorders (Mahmood and Malik, 2013).

It is increasingly difficult to find a river or other bodies of water of which its natural regime has not been modified by man's activities. There is a considerable variation in the sources and concentrations of toxic metals among rivers all over the world. The presence of metal pollutants in freshwater is known to disturb the delicate balance of aquatic ecosystem (Abdus-salam et al., 2008). The aquatic systems receive a large amount of heavy metals from natural occurring deposits and natural processes and anthropogenic activities (Salano, 2013). 
Soil is often contaminated by human activities and this is reflected in the high horizontal and vertical variability brought about by the anthropogenic influence on soil formation and development (Salano, 2013). Large areas of agricultural land are contaminated by heavy metals that mainly originate from former or current mining activities, industrial emissions or the application of sewage sludge (Issa, 2008). Amaranths (Amaranthus species) are grown during both wet and dry season, though irrigation is normally required for dry season crops since the rate of transpiration by the leaves is usually high. Amaranth can tolerate a soil $\mathrm{pH}$ of 4.5 to 8 (Fayemi, 1999). The leaves are rich in calcium, phosphorus, folic acid, potassium, iron and vitamins $\mathrm{A}, \mathrm{B}$ and $\mathrm{C}$ but fairly low in carbohydrate (Okpara et al., 2013). Amaranths are recommended as a good food with medicinal properties for pregnant women, children lactating mothers and patients with constipation, fever, haemorrhage and anaemia (Quinton, 2006).

The level of heavy metals (As, Cd, $\mathrm{Co}, \mathrm{Cu}, \mathrm{Fe}, \mathrm{Ni}, \mathrm{Pb}$ and $\mathrm{Zn}$ ) in soils samples from farmland around dumpsite as well as other sites used as control sites in Lafia metropolis, Nasarawa state, Nigeria have been determined by Opaluwa et al. (2012). The values of all the metals analyzed for samples from dumpsites were higher than those from the control site suggesting possible mobility of metals from dumpsites to farmlands through leaching and runoffs, but were below values recommended by the World Health Organization (WHO).

Soil samples irrigated with two different water sources; ground water zone (GWZ) and waste water zone (WWZ) have been analyzed for some heavy metals Chromium, Cobalt, Nickel,
Copper, Lead, Cadmium, Manganese and Zinc. Concentration of heavy metals of soil obtained from different sites of WWZ was found to be significantly high as compared to the soil obtained from various sites of GWZ (Mahmood and Malik, 2013). Accumulation of heavy metals such as cadmium (Cd), copper $(\mathrm{Cu})$, manganese $(\mathrm{Mn})$, lead $(\mathrm{Pb})$ and zinc ( $\mathrm{Zn}$ ) in some Amaranthus spp grown around refuse and industrial effluent site, have been reported by Shagal et al., (2012) with the results revealing high concentration of the metals ranged from $10.00-70.50 \mathrm{mg} / \mathrm{Kg}$ of various heavy metals.

A comparative studied of heavy metals (Lead $(\mathrm{Pb})$, Zinc ( $\mathrm{Zn})$ and Cadmium (Cd)) contamination in the vegetable Corchorus olitorius (C. olitorius) leaves cultivated along a major road and remote area free from any form of industrial activities have also been carried out by Sanyaolu et al. (2007) with the results indicating that the closer the plants were to the road, the higher the heavy metal burden compare to the concentration of heavy metals in C.olitorius leaves from the control site which remains constant (i.e. showing no sign of contamination).

Amaranthus randomly collected from agricultural fields at five different stations across Vrishabhavathi River in the south of the Indian city of Bengaluru have been analyzed for $\mathrm{Fe}, \mathrm{Zn}, \mathrm{Cd}, \mathrm{Cr}, \mathrm{Cu}, \mathrm{Mn}$, and $\mathrm{Pb}$ with the highest transfer factor of the metals from the river water to the vegetable in the order of $\mathrm{Zn}>\mathrm{Mn}>\mathrm{Fe}>\mathrm{Cu}>\mathrm{Ni}>\mathrm{Pb}>\mathrm{Cr}$ (Jayadev and Puttaih, 2013). However, the results obtained from the various studies on the heavy metals determination were not subjected to risk and hazard assessment.

This study aims at the risk assessment of selected heavy metals by estimating the bioaccumulation factor that exists in 
the vegetable, evaluating the possible health hazards to human body through the consumption of the vegetable and to determine the correlation between the metals concentration in soil and Amaranthus leaves.

\section{Materials and Method Study Area}

The study was conducted on the Agricultural Research and Learning

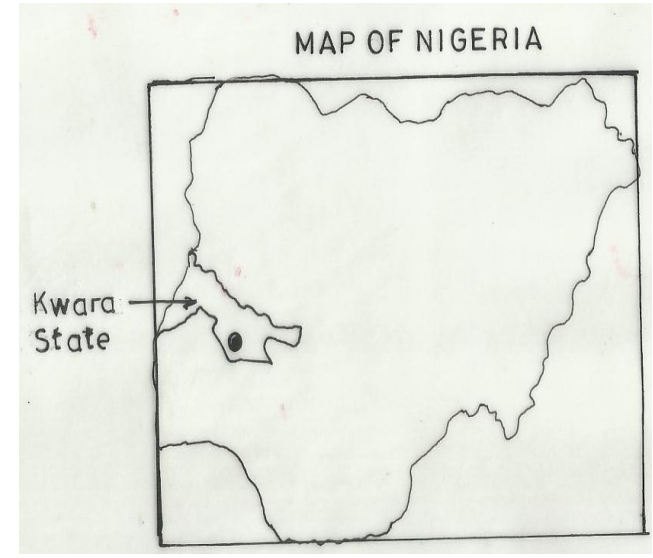

(a)
Vegetable Farm, University of Ilorin, Ilorin, Kwara state. The university lies between Latitude $8.47^{\circ} \mathrm{N}$ and Longitude $4.68{ }^{\circ} \mathrm{E}$. The Vegetable Farm covers an area of half of an hectare and is located close to the maize farm which is $1 \frac{1 / 2}{2}$ hectare situated along the university road; a major highway with quite heavy vehicular movement throughout the day.

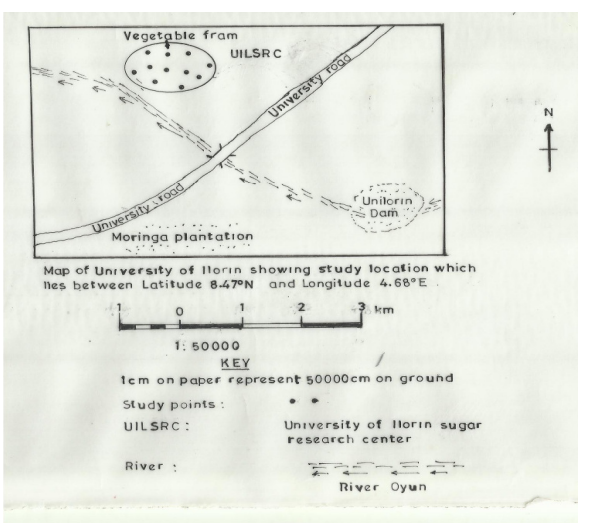

(b)

Figure 1: (a) Map of Nigeria showing Kwara state and the state capital, Ilorin (b) Scale Map of University of Ilorin showing the study location

\section{Sampling and Preparation}

All samples were taken during the dry season between February and March and were immediately taken to the laboratory after collection for preparation and stored adequately until digestion and analysis.

Surface water sample of the Oyun River used for irrigation was taken in a well labeled plastic container. About 500 $\mathrm{ml}$ of irrigation water was collected and stored in the refrigerator at about $5{ }^{\circ} \mathrm{C}$ temperature prior to analysis. Sampling spots were mapped out at reasonable distance from each other using the quadrant sampling method. A total of 17 soil samples of about $500 \mathrm{~g}$ each were collected from the surface soil from 0-5 $\mathrm{cm}$ depth using augers. Collected soil samples were put in polythene bags and labeled SS01 - SS017 then closed tightly and taken to the laboratory. The collected soil samples were air dried for 24 hours and pulverized using a wooden mortar and pestle; pebbles and plant fragments were removed. The ground soil samples were screened through a $2 \mathrm{~mm}$ sieve and stored in a dark cupboard until digestion.

Samples of Amaranthus spp. were also taken on the same day using the quadrant sampling method. The vegetable was taken with the roots, labeled (PS01 - PS17) accordingly and taken to the laboratory in polythene bags. The plant samples were rinsed with tap water and then with distilled water. The leaves of the vegetable were taken and 
oven dried at exactly $70^{\circ} \mathrm{C}$ until a constant weight is achieved to remove all combined water and achieve good homogenization and correct analytical results (Estefan et al., 2013). The dried plant samples were ground and sieved through a $1 \mathrm{~mm}$ sieve then labeled and stored in a dark cupboard.

\section{Determination of physicochemical parameters}

The irrigation water was analyzed for some physicochemical parameters such as $\mathrm{pH}$, Electrical Conductivity (EC), Total Suspended Solids (TSS), Total Dissolved Solids (TDS). The $\mathrm{pH}$ value of the water sample was measured using the Hanna $\mathrm{pH} 20 \mathrm{pH}$ meter and electrical conductivity was measured with the EC 214 conductivity meter at $25^{\circ} \mathrm{C}$. Total Suspended Solids was determined following a standard method (Nasrullah et al., 2006). While TDS value was obtained using the conductivity method (Uwidia and Ukulu, 2013)

\section{Sample Digestion and the determination of Heavy metals}

Samples of irrigation water, Soil and vegetables were digested using the mixed acid hot plate digestion method (Hogan, 2011). The resulting solutions were analyzed for heavy metals ( $\mathrm{Fe}, \mathrm{Cd}, \mathrm{Co}$, $\mathrm{Cu}, \mathrm{Mn}, \mathrm{Cr}, \mathrm{Ni}, \mathrm{Pb}$ and $\mathrm{Zn}$ ) using atomic absorption spectrophotometer; BUCK SCIENTIFIC MODEL 210 VGP

\section{Data Analysis}

The results obtained from the AAS equipment was in $\mathrm{mg} / \mathrm{L}$ and were converted to $\mathrm{mg} / \mathrm{kg}$ for dry samples according to Sanyaolu et al., (2011). Estimation of Transfer Factor, Daily Intake Rate and Target Hazard Quotient of Metals, Transfer Factor (Bioaccumulation Factor) was done using standard methods (Naser et al., 2012, Orisakwe et al., 2012, Iwegbue et al., 2013). Length of exposure (ED) was set to 16,936 days for Nigerian based on the average life expectancy of 48.4 years, from 2 years of age (Iwegbue et al., 2013). The average adult body weight (BW) was considered to be $55.9 \mathrm{~kg}$, and average daily vegetable intake for adults (SFI) is considered to be 0.345 $\mathrm{kg} /$ person/day (Orisakwe et al., 2012). $\mathrm{AT}=\mathrm{ED}$ for non-cancer risk (IDNR, 2013). The data were statistically analyzed by SPSS software version 16.0 to obtain the Pearson correlation coefficient between metal concentrations in soil and Amaranthus leaves.

\section{Results}

The results of physicochemical parameters, metal concentrations of samples, transfer factors, daily intake rates, target hazard quotients and coefficients of correlation between metals in soil and Amaranthus leaves and various guidelines are summarized in the tables below.

Table 1: Physical properties of irrigation water sample

\begin{tabular}{llll}
\hline $\mathrm{pH}$ & $\mathrm{EC}\left(\mu \mathrm{S} \mathrm{cm}^{-1}\right)$ & $\mathrm{TSS}\left(\mathrm{mg} \mathrm{L}^{-1}\right)$ & $\mathrm{TDS}\left(\mathrm{mg} \mathrm{L}^{-1}\right)$ \\
\hline 7.1 & 152 & 0.69 & 98.8 \\
\hline
\end{tabular}

Table 2: Concentration of Heavy Metals in irrigation water $(\mathrm{mg} / \mathrm{L})$

\begin{tabular}{llllllllll}
\hline Heavy Metals & $\mathrm{Mn}$ & $\mathrm{Fe}$ & $\mathrm{Cu}$ & $\mathrm{Co}$ & $\mathrm{Cr}$ & $\mathrm{Cd}$ & $\mathrm{Pb}$ & $\mathrm{Ni}$ & $\mathrm{Zn}$ \\
\hline Conc. & 0.41 & 0.30 & 0.02 & 0.00 & 0.00 & 0.00 & 0.00 & 0.00 & 0.02 \\
\hline \multicolumn{8}{c}{485}
\end{tabular}


Table 3: Concentrations of Heavy Metals in soil sample ( $\left.\mathrm{mg} \mathrm{kg}^{-1}\right)$

\begin{tabular}{|c|c|c|c|c|c|c|c|c|c|}
\hline Soil sample & $\mathrm{Mn}$ & $\mathrm{Fe}$ & $\mathrm{Cu}$ & $\mathrm{Cr}$ & $\mathrm{Pb}$ & $\mathrm{Zn}$ & Co & $\mathrm{Cd}$ & $\mathrm{Ni}$ \\
\hline SS01 & 181.0 & 4116.0 & 8.0 & 5.0 & ND & 11.5 & ND & ND & ND \\
\hline $\mathrm{SS} 02$ & 180.0 & 4051.0 & 2.0 & 4.0 & ND & 11.0 & ND & ND & ND \\
\hline SS03 & 255.5 & 5279.0 & 3.0 & 6.0 & 9.5 & 21.0 & ND & ND & ND \\
\hline SS04 & 150.0 & 8679.0 & 3.5 & 4.0 & 11.0 & 12.5 & ND & ND & ND \\
\hline SS05 & 160.0 & 6556.0 & 4.0 & 6.0 & 5.0 & 14.0 & ND & ND & ND \\
\hline SS06 & 205.5 & 6178.5 & 6.0 & 6.5 & 20.0 & 16.5 & ND & ND & ND \\
\hline SS07 & 143.0 & 3842.5 & 2.0 & 4.0 & ND & 18.0 & ND & ND & ND \\
\hline SS08 & 182.0 & 4564.0 & 3.0 & 4.0 & ND & 18.0 & ND & ND & ND \\
\hline SS09 & 177.0 & 3928.0 & 3.0 & ND & ND & 19.0 & ND & ND & ND \\
\hline SS10 & 161.5 & 4055.5 & 3.5 & ND & ND & 17.5 & ND & ND & ND \\
\hline SS11 & 205.5 & 4901.5 & 4.5 & 2.0 & ND & 25.5 & ND & ND & ND \\
\hline SS12 & 126.5 & 4076.5 & 2.5 & 5.5 & ND & 13.5 & ND & ND & ND \\
\hline SS13 & 117.0 & 4828.5 & 4.0 & 8.5 & 33.0 & 21.5 & ND & ND & ND \\
\hline SS14 & 182.5 & 6413.5 & 3.0 & 8.0 & ND & 20.5 & ND & ND & ND \\
\hline SS15 & 76.5 & 2063.5 & 3.5 & ND & ND & 9.0 & ND & ND & ND \\
\hline SS16 & 178.5 & 4167.5 & 4.5 & 5.0 & ND & 16.0 & ND & ND & ND \\
\hline SS17 & 185.0 & 4934.5 & 4.0 & 6.5 & ND & 20.0 & ND & ND & ND \\
\hline
\end{tabular}

$\mathrm{ND}=$ not detected

Table 4: Concentrations of Heavy Metals in Amaranthus spp. (mg/kg)

\begin{tabular}{llllllllll}
\hline Amaranthus & $\mathrm{Mn}$ & $\mathrm{Fe}$ & $\mathrm{Cu}$ & $\mathrm{Co}$ & $\mathrm{Cr}$ & $\mathrm{Cd}$ & $\mathrm{Pb}$ & $\mathrm{Ni}$ & $\mathrm{Zn}$ \\
\hline $\mathrm{A}$ & 635.0 & 452.5 & $\mathrm{ND}$ & $\mathrm{ND}$ & $\mathrm{ND}$ & $\mathrm{ND}$ & $\mathrm{ND}$ & $\mathrm{ND}$ & 100.0 \\
$\mathrm{~B}$ & 940.0 & 480.0 & 10.0 & $\mathrm{ND}$ & $\mathrm{ND}$ & $\mathrm{ND}$ & $\mathrm{ND}$ & $\mathrm{ND}$ & 80.0 \\
$\mathrm{C}$ & 502.5 & 662.5 & $\mathrm{ND}$ & $\mathrm{ND}$ & $\mathrm{ND}$ & $\mathrm{ND}$ & $\mathrm{ND}$ & $\mathrm{ND}$ & 67.5 \\
$\mathrm{D}$ & 530.0 & 405.0 & $\mathrm{ND}$ & $\mathrm{ND}$ & $\mathrm{ND}$ & $\mathrm{ND}$ & $\mathrm{ND}$ & $\mathrm{ND}$ & 50.0 \\
$\mathrm{E}$ & 687.5 & 502.5 & 7.5 & $\mathrm{ND}$ & $\mathrm{ND}$ & $\mathrm{ND}$ & $\mathrm{ND}$ & $\mathrm{ND}$ & 110.0 \\
$\mathrm{~F}$ & 482.5 & 480.0 & $\mathrm{ND}$ & $\mathrm{ND}$ & $\mathrm{ND}$ & $\mathrm{ND}$ & $\mathrm{ND}$ & $\mathrm{ND}$ & 95.0 \\
$\mathrm{G}$ & 645.0 & 407.5 & 7.5 & $\mathrm{ND}$ & $\mathrm{ND}$ & $\mathrm{ND}$ & $\mathrm{ND}$ & $\mathrm{ND}$ & 95.0 \\
$\mathrm{H}$ & 390.0 & 502.5 & $\mathrm{ND}$ & $\mathrm{ND}$ & $\mathrm{ND}$ & $\mathrm{ND}$ & $\mathrm{ND}$ & $\mathrm{ND}$ & 67.5 \\
WHO/FAO & - & 48.0 & 30.0 & - & - & 1.0 & 2.0 & - & 60.0 \\
NAFDAC & - & - & 20.0 & - & - & - & 2.0 & - & 50.0 \\
EC/CODEX & - & - & 0.3 & - & - & 0.2 & 0.3 & - & $\geq 50.0$ \\
Normal range in plants & - & $400-500$ & 2.5 & - & - & $<2.4$ & $0.50-30$ & $0.02-50$ & $20-100$ \\
\hline
\end{tabular}

ND* not detected 
Tables 5: Estimated Daily Intake of Metal $\left(\mathrm{mg} \mathrm{kg}^{-1}\right.$ day $\left.^{-1}\right)$ from ingestion of $0.345 \mathrm{~kg}$ of the vegetable

\begin{tabular}{llllllllll}
\hline Amaranthus & $\mathrm{Mn}$ & $\mathrm{Fe}$ & $\mathrm{Zn}$ & $\mathrm{Cu}$ & $\mathrm{Pb}$ & $\mathrm{Co}$ & $\mathrm{Cd}$ & $\mathrm{Cr}$ & $\mathrm{Ni}$ \\
\hline $\mathrm{A}$ & 3.919 & 2.793 & 0.617 & $\mathrm{NC}$ & $\mathrm{NC}$ & $\mathrm{NC}$ & $\mathrm{NC}$ & $\mathrm{NC}$ & $\mathrm{NC}$ \\
$\mathrm{B}$ & 5.801 & 2.962 & 0.494 & 0.062 & $\mathrm{NC}$ & $\mathrm{NC}$ & $\mathrm{NC}$ & $\mathrm{NC}$ & $\mathrm{NC}$ \\
$\mathrm{C}$ & 3.101 & 4.089 & 0.417 & $\mathrm{NC}$ & $\mathrm{NC}$ & $\mathrm{NC}$ & $\mathrm{NC}$ & $\mathrm{NC}$ & $\mathrm{NC}$ \\
$\mathrm{D}$ & 3.271 & 2.500 & 0.309 & $\mathrm{NC}$ & $\mathrm{NC}$ & $\mathrm{NC}$ & $\mathrm{NC}$ & $\mathrm{NC}$ & $\mathrm{NC}$ \\
$\mathrm{E}$ & 4.243 & 3.101 & 0.679 & 0.046 & $\mathrm{NC}$ & $\mathrm{NC}$ & $\mathrm{NC}$ & $\mathrm{NC}$ & $\mathrm{NC}$ \\
$\mathrm{F}$ & 2.976 & 2.962 & 0.586 & $\mathrm{NC}$ & $\mathrm{NC}$ & $\mathrm{NC}$ & $\mathrm{NC}$ & $\mathrm{NC}$ & $\mathrm{NC}$ \\
$\mathrm{G}$ & 3.981 & 2.515 & 0.586 & 0.046 & $\mathrm{NC}$ & $\mathrm{NC}$ & $\mathrm{NC}$ & $\mathrm{NC}$ & $\mathrm{NC}$ \\
$\mathrm{H}$ & 2.407 & 3.101 & 0.417 & $\mathrm{NC}$ & $\mathrm{NC}$ & $\mathrm{NC}$ & $\mathrm{NC}$ & $\mathrm{NC}$ & $\mathrm{NC}$ \\
Integrated Risk & 11.0 & 45.0 & 40.0 & 10.0 & 0.240 & - & 0.064 & 0.0105 & \\
Information System (US & & & & & & & & & \\
EPA 2009) & & & & & & & & &
\end{tabular}

Table 6: Estimated Target Hazard Quotient of Metal ion

\begin{tabular}{llllllllll}
\hline Amaranthus & $\mathrm{Mn}$ & $\mathrm{Fe}$ & $\mathrm{Zn}$ & $\mathrm{Cu}$ & $\mathrm{Pb}$ & $\mathrm{Co}$ & $\mathrm{Cd}$ & $\mathrm{Cr}$ & $\mathrm{Ni}$ \\
\hline $\mathrm{A}$ & $2.79 \times 10^{-2}$ & $3.98 \times 10^{-3}$ & $2.10 \times 10^{-3}$ & $\mathrm{NC}$ & $\mathrm{NC}$ & $\mathrm{NC}$ & $\mathrm{NC}$ & $\mathrm{NC}$ & $\mathrm{NC}$ \\
$\mathrm{B}$ & $4.14 \times 10^{-2}$ & $4.22 \times 10^{-3}$ & $1.68 \times 10^{-3}$ & $1.50 \times 10^{-3}$ & $\mathrm{NC}$ & $\mathrm{NC}$ & $\mathrm{NC}$ & $\mathrm{NC}$ & $\mathrm{NC}$ \\
$\mathrm{C}$ & $2.21 \times 10^{-2}$ & $5.83 \times 10^{-3}$ & $1.42 \times 10^{-3}$ & $\mathrm{NC}$ & $\mathrm{NC}$ & $\mathrm{NC}$ & $\mathrm{NC}$ & $\mathrm{NC}$ & $\mathrm{NC}$ \\
$\mathrm{D}$ & $2.33 \times 10^{-2}$ & $3.56 \times 10^{-3}$ & $1.05 \times 10^{-3}$ & $\mathrm{NC}$ & $\mathrm{NC}$ & $\mathrm{NC}$ & $\mathrm{NC}$ & $\mathrm{NC}$ & $\mathrm{NC}$ \\
$\mathrm{E}$ & $3.03 \times 10^{-2}$ & $4.42 \times 10^{-3}$ & $2.31 \times 10^{-3}$ & $1.13 \times 10^{-3}$ & $\mathrm{NC}$ & $\mathrm{NC}$ & $\mathrm{NC}$ & $\mathrm{NC}$ & $\mathrm{NC}$ \\
$\mathrm{F}$ & $2.12 \times 10^{-2}$ & $4.22 \times 10^{-3}$ & $2.00 \times 10^{-3}$ & $\mathrm{NC}$ & $\mathrm{NC}$ & $\mathrm{NC}$ & $\mathrm{NC}$ & $\mathrm{NC}$ & $\mathrm{NC}$ \\
$\mathrm{G}$ & $2.84 \times 10^{-2}$ & $3.59 \times 10^{-3}$ & $2.00 \times 10^{-3}$ & $1.13 \times 10^{-3}$ & $\mathrm{NC}$ & $\mathrm{NC}$ & $\mathrm{NC}$ & $\mathrm{NC}$ & $\mathrm{NC}$ \\
$\mathrm{H}$ & $1.72 \times 10^{-2}$ & $4.42 \times 10^{-3}$ & $1.42 \times 10^{-3}$ & $\mathrm{NC}$ & $\mathrm{NC}$ & $\mathrm{NC}$ & $\mathrm{NC}$ & $\mathrm{NC}$ & $\mathrm{NC}$ \\
\hline
\end{tabular}

$\mathrm{NC}^{*}$ not calculated.

\section{Discussion}

\section{Heavy Metal Contents of Irrigation} Water, Soil and Amaranthus Leaves

The maximum concentration of iron in soil was in $\mathrm{SS} 04(8676 \mathrm{mg} / \mathrm{kg})$ and minimum in SS15 $(2063 \mathrm{mg} / \mathrm{kg}$ ) (Table 3). While in the vegetable leaves the concentration was highest in sample $\mathrm{C}$ $(662.5 \mathrm{mg} / \mathrm{kg})$ and least in sample D $(405.0 \mathrm{mg} / \mathrm{kg})($ Table 4$)$. The level of Fe in irrigation water was below the Canadian standard but was higher than the FAO standard for vegetables in some cases.

The concentration of manganese in soil was maximum in SS03 (225.5 $\mathrm{mg} / \mathrm{kg}$ ) and minimum in SS15 (76.5 $\mathrm{mg} / \mathrm{kg}$ ) (Table 3). While in the vegetable leaves the concentration was highest in sample B $(940.0 \mathrm{mg} / \mathrm{kg})$ and least in sample $\mathrm{H}(390.0 \mathrm{mg} / \mathrm{kg})$ (Table 4). The level of $\mathrm{Mn}$ in irrigation water exceeded the Canadian and WHO/FAO guidelines and below the EU standards for all soil samples with levels in Amaranthus spp above the FAO guidelines. Manganese toxicity is a major factor on limiting growth in acidic soils, in these soils high concentrations of manganese in the leaves reduces photosynthesis and thus growth is reduced (Mousavi et al., 2011) as observed in the Amaranthus spp. 
In irrigation water and soil, Zn levels were below the international standards while only one sample of the Amaranthus spp. had $\mathrm{Zn}$ level above the FAO standard (Tables 2, 3 and 4). Zinc is a trace element that can affect several metabolic processes of plants at high concentrations. Zinc deficiency has been shown to be associated with increased morbidity and mortality, in particular from diarrhea, possibly also from malaria, and also with reduced child growth (Nubé and Voortman, 2006).

The mean concentrations of $\mathrm{Cu}$ in irrigation water, soil and Amaranthus spp. were the ranges of $0.02 \mathrm{mg} / \mathrm{L}, 2.0-$ $8.0 \mathrm{mg} / \mathrm{kg}$ and $0.00-10.0 \mathrm{mg} / \mathrm{kg}$ respectively. In all the samples analyzed, the levels of $\mathrm{Cu}$ were below all standards (Tables 2, 3 and 4).

Chromium concentration in soil was maximum at $\mathrm{SS} 13(8.5 \mathrm{mg} / \mathrm{kg})$ and minimum at SS11 $(2.0 \mathrm{mg} / \mathrm{kg})$ and were not detected in SS09, SS10 and SS15 (Table 3). $\mathrm{Cr}$ levels were below the Canadian and EU standards. $\mathrm{Cr}$ was not detected in the Amaranthus spp. and this might be due to the quality of the irrigation water, however a little concentration $\mathrm{Cr}$ can be very toxic and will pose great health hazards.

Lead concentration in the soil sample analyzed was in the range of $5.0 \mathrm{mg} / \mathrm{kg}-$ $33.0 \mathrm{mg} / \mathrm{kg}$ and was only detected in 5 soil samples out of 17 samples analyzed. $\mathrm{Pb}$ was not detected in any of the Amaranthus samples as well as the irrigation water sample. Lead is well known for its toxic and adverse effects on human. Its absence in the plant will give no deficiency symptoms as it is nonessential.

Heavy metals like cadmium, lead, and nickel are highly toxic at relatively low concentrations in human beings and animals (Latif, 2009). Cobalt, cadmium and nickel were not detected in all the samples of water, soil and vegetables analyzed. This shows that the location of the university road has no influence on the concentration of $\mathrm{Co}, \mathrm{Cd}$ and $\mathrm{Ni}$ in the environment as well as $\mathrm{Pb}$ and $\mathrm{Cr}$ in the vegetable. Although the farmland is close to a major road (the university road), exhaust from vehicles are expected to increase the concentration of metals like Zinc, Copper, Lead, Nickel and Cadmium; but this was not the case due to adequate dispersion. Fe has the highest concentration of all the heavy metals detected in the soil and this has been reported for Ilorin and its environs soil (Dosumu et al., 2002).

Transfer Factor, Daily Intake Rate and Target Hazard Quotient of Metals

The relative orders of transfer of metals from soil to plants grown on soil irrigated with river water were $\mathrm{Zn}>\mathrm{Mn}>$ $\mathrm{Cu}>\mathrm{Fe}$ with TFs 4.957, 3.570, 0.830 and 0.100 respectively. The TFs indicate that uptake of metals by crops does not increase linearly with increasing concentrations of metals in soils (Fe $>\mathrm{Mn}>\mathrm{Zn}>\mathrm{Cu}$ ) as reported by Rattan et al., (2005). Zinc was found to have the highest TF as also found by Jayadev and Puttaih (2013) in their study with Amaranthus spp.

The daily intake rates of these metals were below the US EPA (2009) upper tolerable daily intake for both adults and children (Table 6). Mn was found to have the highest DIR while copper had the lowest. They were in ranges; $\mathrm{Mn}$ $(2.407-5.801 \mathrm{mg} / \mathrm{kg} /$ day $), \mathrm{Fe}(2.500-$ $4.089 \mathrm{mg} / \mathrm{kg} /$ day $), \mathrm{Zn}(0.309-0.679$ $\mathrm{mg} / \mathrm{kg} / \mathrm{day})$, and $\mathrm{Cu}(0.046-0.062$ $\mathrm{mg} / \mathrm{kg} /$ day). 
The THQs for metals obtained in this study were all below 0.1 in ranges; $\mathrm{Zn}$ $\left(1.05 \times 10^{-3}-2.31 \times 10^{-3}\right)$, Mn $\left(1.72 \times 10^{-2}\right.$ $\left.4.14 \times 10^{-2}\right), \mathrm{Fe}\left(3.56 \times 10^{-3} 5.83 \times 10^{-3}\right)$ and $\mathrm{Cu}\left(1.13 \times 10^{-3} 1.50 \times 10^{-3}\right)$. Hence, this implies that the prolonged consumption of these vegetables will have no toxic effect on the consumers as the THQ less than or equal to 1 represents no adverse effect for non-carcinogen (IDNR, 2013).

\section{Coefficient of Correlation between Metal Concentrations in Soil and Amaranthus Leaves}

The coefficient of correlation between metals in soil and Amaranthus leaves revealed that metal levels increase in Amaranthus leaves and the metal level of the soil decreases slightly and vice versa. However, the relationship between the metal level in soil and Amaranthus leaves were negligible with coefficient of correlation of $-0.286,-0.120,-0.152$ and 0.525 for $\mathrm{Mn}, \mathrm{Fe}, \mathrm{Zn}$, and $\mathrm{Cu}$ respectively. These generally mean that the concentration of metals in the Amaranthus leaves cannot be attributed to the metal concentration of the soil.

\section{Conclusion}

The study has shown that there was considerable amount of heavy metals in irrigation water, soil and Amaranthus spp., though the levels were below the international standards' permissible levels for $\mathrm{Cu}, \mathrm{Pb}$, and $\mathrm{Cr}$. In few cases the levels of $\mathrm{Mn}, \mathrm{Fe}$ and $\mathrm{Zn}$ exceeded the permissible limit of some of the internationals standards. The heavy metals concentration in the river water and in the Amaranthus leaves was found to be in the order; $\mathrm{Mn}>\mathrm{Fe}>\mathrm{Zn}>\mathrm{Cu}$, while other heavy metals of interest were not detected. The present study has shown that the quality of water for long term irrigation has great impact on the heavy metal content of vegetables irrigated with it. There was no strong relationship between the metal levels in soil and the leaves of the vegetable according to the results of correlation coefficient. The data however revealed that iron, manganese and Zinc has antagonistic effect on the availability of copper and Amaranthus spp. is not likely to induce any health hazard to consumers as far as its metal contents and the calculated target hazard quotient are concerned. Hence, the vegetables would serve as a great source of the most essential nutrients needed by both plant and animals. However, the level of Fe, $\mathrm{Zn}$ and $\mathrm{Mn}$ in the soil should be continuously monitored to check on their levels in order to avoid toxicity overtime.

\section{References}

Abdus-Salam, N., Adekola, F.A. and Bolorunduro, O.J. (2008). Environmental Assessment of the Impact of Feed Water on the Quality of Sugarcane Juice. International Jour. Chem., 18(3):129-135.

Audu, A.A. and Lawal, A.O. (2006). Variation in Metal Contents of Plants in Vegetable Garden Sites in Kano Metropolis. J. Appl. Sci. Environ. Mgt., 10(2):105 - 109.

Dosumu, O.O., Salami, N. and Adekola, F.A. (2003).Comparative Study of Trace Element Levels in Some Local Vegetable Varieties and Irrigation Waters from Different Locations in Ilorin, Nigeria. Bull. Chem. Soc. Ethiop., 17(1):107-112.

Estefan, G., Sommer, R. and Ryan, J. (2013). Methods of Soil, Plant, and 
Water Analysis: A Manual for the West Asia and North Africa Region $3^{\text {rd }}$ Edition. ICARDA (International Center for Agricultural Research in the Dry Areas).

Fayemi, P.O. (1999). Nigerian Vegetables. Heinaman Educational Book Plc. Ibadan, Nigeria, Pp.5759.

Hogan, M.C. (2011). Minerals, mining and toxicology. Retrieved from: www.eoearth.org

IDNR (Iowa Department of Natural Resources) (2013). Explanation of Risk Assessments and Development of Risk-Based Standards. Contaminated Sites Section. Iowa Administrative Code 133.

Issa, I. A. (2008). Investigation of Heavy Metals Solubility and Redox Properties of Soils. (Ph.D thesis, SzentIstvan University, Godollö, Hungary).

Iwegbue, C.M.A., Nwozo, S.O., Overah, C.L., Bassey, F.I. and Nwajei, G.E. (2013). Concentrations of Selected Metals in Some Ready-To-EatFoods Consumed in Southern Nigeria: Estimation of Dietary Intakes and Target Hazard Quotients. Turkish Journal of Agriculture - Food Science and Technology, 1(1): 1-7.

Jayadev, Puttaih E.T.(2013). Assessment of heavy metals uptake in leafy vegetables grown on long term wastewater irrigated soil across Vrishabhavathi River, Bangalore, Karnataka. IOSR Journal of Environmental Science, Toxicology and Food Technology, 7(6): 52-55. www.iosrjournals.org

Jolly, Y.N., Islam, A. and Akbar, S. (2013). Transfer of Metals from
Soil to Vegetables and Possible Health Risk Assessment. Springer Plus Open Journal, Vol.2:385.

Latif, M.I. (2009). Quantitative Assessment of Heavy Metals in Soils and Vegetables Irrigated with Sewage in Rawalpindi Area (Ph.D Thesis, Arid Agriculture University Rawalpindi, Pakistan).

Mahmood, A. and Malik, R.N. (2013). Human Health Risk Assessment of Heavy Metals Via Consumption of Contaminated Vegetables Collected from Different Irrigation Sources in Lahore, Pakistan. Special Issue: Environmental Chemistry. Arabian Journal of Chemistry, 7: 91-99.

Mousavi, S.R., Shahsavari, M. and Rezaei, M. (2011). A General Overview on Manganese (Mn) Importance for Crops Production. Australian Journal of Basic and Applied Sciences, 5(9): 1799-1803.

Nagajyoti, P.C., Lee, K.D. and Sreekanth, T.V.M. (2010). Heavy Metals, Occurrence and Toxicity for Plants: A Review. Environ. Chem. Lett., 8:199-216.

Naser, H.M., Mahmud, N.H., Sultana, S., Gomes, R. and Rahman, M. (2012). Trace Elements Content in Vegetables Grown in Industrially Polluted and Non-Polluted Areas. Bangladesh J. Agril. Res, 37(3): 515-527.

Nasrullah, Naz, R., Bibi, H., Iqbal, M. and Durrani, M.I. (2006). Pollution Load in Industrial Effluent and Ground Water of Gadoon Amazai Induatrial Estate (Gaie) Swabi, Nwfp. Journal of Agricultural and Biological Science, 1(3): 18-24.

Nubé, M. and Voortman, R.L. (2006). Simultaneously addressing 
micronutrient deficiencies in soils, crops, animal and human nutrition: opportunities for higher yields and better health. The Centre for World Food Studies (Dutch acronym SOW-VU), Pp.1-41.

Okpara, S.C., Onyegbule, U.N., Nwanguma, E.I., Ibekwe, H.N., Ngbede, S.O. and Uwalaka, O.A. (2013). Effect of Different Fertilizer Forms on the Growth and Yield of Amaranths (Amaranthus cruentus) in Okwigwe, Southeastern Nigeria. Horticultural Society of Nigeria (Hortson) Book of Abstract 31st Annual Conference Held at Raw Materials Research and Development Council Abuja 22nd26th September, 2013, Pp.86.

Opaluwa, O.D., Aremu, M.O., Ogbo, L.O., Abiola, K.A., Odiba, I.E., Abubakar, M.M. and Nweze, N.O. (2012). Heavy Metal Concentrations in Soils, Plant Leaves and Crops Grown around Dump Sites in Lafia Metropolis, Nasarawa State, Nigeria. Advances in Applied Science Research, 3(2): 780-784.

Orisakwe, O.E., Nduka, J.K., Amadi, C.N., Dike, D. and Obialor, O.O. (2012). Evaluation of Potential Dietary Toxicity of Heavy Metals of Vegetables. Journal of Environment and Analytic Toxicology, 2:136.

Quinton, I. (2006). Indigenous Spinach. Go Farming for the Farmers of Tomorrow, Pp. 2021.

Ramesh, H.L. and Yogananda, M.V.N. (2012). Assessment of Heavy Metal Contamination in Green Leafy Vegetables Grown in Bangalore Urban District of Karnataka.
Advances in Life Science and Technology, Vol.6.

Rasheed, M.N. and Awadallah, R.M. (1998). Trace elements in Faba bean (Vica faba L.) plant and soil as determined by atomic absorption spectrophotometer and ion selective electrode. Journal of Science, Food and Agriculture, 77: 18 -24.

Rattan, R.K., Datta, S.P., Chhonkar, P.K., Suribabu, K. and Singh, A.K. (2005). Long-Term Impact of Irrigation with Sewage Effluents on Heavy Metal Content in Soils, Crops and Groundwater: A Case Study. Agriculture, Ecosystems and Environment, 109: 310-322.

Salano, E.M. (2013). Assessment of Heavy Metal Pollution in Soils and Water of Samburu County, Kenya (Master Thesis, Kenyatta University, Kenya).

Sanyaolu, V.T., Sanyaolu, A.A.A. and Fadele, E. (2011). Spatial Variation in Heavy Metal Residue in Corchorus olitorious Cultivated Along a Major Highway in Ikorodu- Lagos, Nigeria. J. Appl. Sci. Environ. Manage., 15(2): 283 287.

Shagal, M.H., Maina, H.M., Donatus, R.B. and Tadzabia, K. (2012). Bioaccumulation of trace metals concentration in some vegetables grown near refuse and effluent dumpsites along Rumude-Doubeli bye-pass in Yola North, Adamawa State. Global Advanced Research Journal of Environmental Science and Toxicology, 1(2): 018 - 022.

Statistics How To (2015). Correlation Coefficients: Find Pearson's Correlation Coefficient. Retrieved from; 
http://www.statisticshowto.com/ho w-to-compute-pearsons-correlationcoefficients.

U.S. Environmental Protection Agency (USEPA) (2005). Ecological Soil Screening Levels for Cobalt. Interim Final Oswer Directive, 9285: 7-67.

Uwidia, I.E. and Ukulu, H.S. (2013). Studies on Electrical Conductivity and Total Dissolved Solids Concentration in Raw Domestic Wastewater obtained from an Estate in Warri, Nigeria. Greener Journal of Physical Sciences, 3(3): 110-114. Wikipedia (2015). Atomic Absorption Spectroscopy. Retrieved From;Http://En.Wikipedia.Org/W/I ndex.Php?Title=Atomic_Absorptio n_Spectroscopy\&Oldid $=646837742$ 